\title{
Identification and characterization of a vancomycin- resistant Staphylococcus aureus isolated from Kolkata (South Asia)
}

Correspondence

Manjusri Bal

manjusrb@vsnl.net

Received 2 January 2007

Accepted 8 August 2007

\author{
Biswajit Saha, ${ }^{1}$ Anil K. Singh, ${ }^{2}$ Abhrajyoti Ghosh $^{3}$ and Manjusri Bal ${ }^{1}$ \\ ${ }^{1}$ Microbiology Laboratory, Department of Physiology, University College of Science, \\ Technology and Agriculture, University of Calcutta, Kolkata, India \\ ${ }^{2}$ Department of Chemistry, Bose Institute, Kolkata, India \\ ${ }^{3} \mathrm{Dr}$ B. C. Guha Centre for Genetic Engineering and Biotechnology, University College of Science, \\ Technology and Agriculture, University of Calcutta, Kolkata, India
}

\begin{abstract}
A pathogenic vancomycin-resistant Staphylococcus aureus (VRSA) isolate (MIC $\geqslant 64 \mu \mathrm{g} \mathrm{ml}^{-1}$ ) was obtained from a Kolkata hospital in June 2005. Species identification was confirmed by Gram staining, standard biochemical tests and PCR amplification of the nuc gene, which encodes the thermostable nuclease that is highly specific for $S$. aureus. The VRSA isolate was also resistant to beta-lactams (amoxicillin, ampicillin, cefepime, cefotaxime, cefuroxime, cephalexin and meticillin), chloramphenicol, streptomycin, macrolides (erythromycin and roxithromycin),

clindamycin, rifampicin and trimethoprim-sulfamethoxazole. However, the isolate was susceptible to gentamicin (an aminoglycoside) and ciprofloxacin (a fluoroquinolone). The resistance to vancomycin was inducible in vitro, because the MIC of vancomycin increased from $64 \mathrm{\mu g} \mathrm{ml}^{-1}$ initially to $1024 \mathrm{\mu g} \mathrm{ml}^{-1}$ during culture of this VRSA strain in the presence of vancomycin. The VRSA isolate contained a large plasmid $(\sim 53.4 \mathrm{~kb})$ and four small plasmids of $\sim 6,5.5,5.1$ and $1.5 \mathrm{~kb}$. The large plasmid of $\sim 53.4 \mathrm{~kb}$ harboured the vancomycin-resistance genes vanHAX, which was confirmed by PCR amplification using the same plasmid as template and, separately, primers specific for the $2.61 \mathrm{~kb}$ vanHAX gene cluster, vanH (969 bp), vanA (1032 bp) and $\operatorname{vanX}(609 \mathrm{bp})$. The VRSA isolate was also positive for mecA. Vancomycin resistance was successfully transferred from this VRSA donor to a vancomycin-sensitive recipient $S$. aureus clinical isolate by a broth mating procedure. The MIC of vancomycin for the transconjugant was $32 \mu \mathrm{g} \mathrm{ml}^{-1}$, as against $2 \mu \mathrm{g} \mathrm{ml}^{-1}$ for the parent strain. Nucleotide sequencing of the PCR product showed partial homology with van genes of an enterococcal transposon Tn1546-like element. This is believed to be the first Indian $S$. aureus isolate that has been shown to be phenotypically vancomycin-resistant, presumably due to a vanHAX analogue.
\end{abstract}

\section{INTRODUCTION}

Only four vancomycin-resistant Staphylococcus aureus (VRSA) isolates have been reported so far from the USA (Chang et al., 2003; Tenover et al., 2004; CDC, 2004; Weigel et al., 2007; Perichon \& Courvalin, 2006). There has been no report of a van gene-mediated VRSA from Asia as yet, except for vancomycin-intermediate S. aureus (VISA) in Japan (CDC, 1997) and Korea (Kim et al., 2000). Recently, Tiwari \& Sen (2006) have reported a VRSA which is van gene-negative. Staphylococcus can cause a variety of suppurative diseases in man, including skin, heart-valve,

Abbreviations: DAD, disc agar diffusion; PG, peptidoglycan; VRSA, vancomycin-resistant $S$. aureus; VSSA, vancomycin-sensitive $S$. aureus.

The GenBank/EMBL/DDBJ accession numbers for the $S$. aureus sequences determined in this paper are EU019995 and EU016096. blood and bone infections (Morse, 1980). More than $90 \%$ of Staphylococcus strains are resistant to penicillin (Chambers, 2001), followed by increasing resistance to meticillin, aminoglycosides, macrolides and lincosamide (Dickgiesser \& Kreiswirth, 1986; Levin et al., 2005; Munckhof et al., 2002; Schmitz et al., 2000). In view of this antibiotic resistance, vancomycin has been the drug of last resort. Vancomycin, a glycopeptide antibiotic, acts against Gram-positive bacteria only, by inhibiting the incorporation of NAM-NAG-polypeptide into the growing peptidoglycan (PG) chain. It inhibits this process by reacting with D-Ala-D-Ala, which consequently blocks the release of terminal D-Ala and intrachain bond formation. Vancomycin-resistant Enterococcus faecium harbours the vanA operon, which contains five genes, vanS, $-R,-H,-A$ and $-X$ (Arthur et al., 1993). vanS and vanR are the regulator genes (Wright et al., 1993). VanH is a 
D-hydroxyacid dehydrogenase that reduces pyruvate to Dlactate (Bugg et al., 1991a), which could be used by VanA ligase in conjunction with ATP and D-Ala to make a D-AlaD-lactate depsipeptide (Bugg et al., 1991b), which is incorporated into the PG layer. Vancomycin binds to $\mathrm{N}$ acyl-D-Ala-D-lactate with an affinity 1000-fold lower than that of $N$-acyl-D-Ala-D-Ala (Bugg et al., 1991b). VanX is a dipeptidase required for the hydrolysis of D-Ala-D-Ala (Reynolds et al., 1994).

Conjugative transfer of high-level vancomycin resistance from Enterococcus faecalis to S. aureus (Noble et al., 1992), and transfer of glycopeptide- and macrolide-resistance genes by transconjugation among enterococci and from Ent. faecalis to S. aureus (Młynarczyk et al., 2002), have been reported. Vancomycin-resistance gene acquisition by S. aureus from Ent. faecium in the clinical environment has also been reported by Weigel et al. (2007).

In this study, we have shown the emergence of vancomycin resistance in Kolkata, India, and its conjugative transfer from one clinical strain to another.

\section{METHODS}

Bacterial strains. Fifty-seven non-repeat clinical isolates of $S$. aureus were collected from various Kolkata hospitals, namely the Calcutta Medical College and Hospital, the School of Tropical Medicine, the Institute of Child Health, the R. G. Kar Medical College and Hospital, the Nilratan Sirkar Medical College and Hospital, and the Seth Sukhlal Karnani Medical College and Hospital, from January 2002 to December 2005. Earlier, 126 strains of S. aureus were collected from the Calcutta Medical College and Hospital during the period November 1985 to September 1988. All these strains were collected to study the antibiotic-resistance profile of $S$. aureus. All cultures were grown on nutrient agar (NA) medium and purified by a single colony isolation technique on NA containing $10 \%$ sodium chloride. Escherichia coli V517 was obtained from National Institute of Cholera and Enteric Disease (NICED).

Confirmation of species identification. Identification of the clinical isolates of $S$. aureus was performed by traditional biochemical tests, including catalase, coagulase and mannitol fermentation tests, and Gram staining (Bannerman, 2003; Turk \& Porter, 1978). PCR amplification of the nuc gene (Brakstad et al., 1992) was performed only for VRSA STM2. PCR amplification of $16 \mathrm{~S}$ rDNA was also performed for VRSA STM2, induced STM2, MC48 and transconjugant T48.

Antibiotic susceptibility testing. The antibiotic-resistance profile was determined by the disc agar diffusion (DAD) technique (Acar, 1980; Bauer et al., 1966), using 18 antibiotic discs. Among these antibiotics, some discs were prepared in the Microbiology Laboratory, Department of Physiology, and a few were obtained commercially from Himedia. The antimicrobials, the manufacturers and the amounts $(\mu \mathrm{g})$ of antimicrobial per disc were as follows: amoxicillin (Rexcel, $30 \mu \mathrm{g}$ ), ampicillin (Biochem Pharmaceutical Industries, $10 \mu \mathrm{g}$ ), cefepime (Unichem Laboratories, $30 \mu \mathrm{g}$ ), cefotaxime (Alkem Laboratories, $30 \mu \mathrm{g}$ ), cefuroxime (Glaxo Smith Kline, $30 \mu \mathrm{g}$ ), cephalexin (Ranbaxy, $30 \mu \mathrm{g}$ ), chloramphenicol (Sigma, $30 \mu \mathrm{g})$, ciprofloxacin [Pharma(Ran), $5 \mu \mathrm{g}$ ], clindamycin (Indipharma, $2 \mu \mathrm{g}$ ), erythromycin (Alembic, $15 \mu \mathrm{g}$ ), gentamicin (Nicholas, $10 \mu \mathrm{g}$ ), meticillin (Himedia, $5 \mu \mathrm{g}$ ), oxacillin (Himedia,
$1 \mu \mathrm{g}$ ), rifampicin (Lupin, $5 \mu \mathrm{g}$ ), roxithromycin (Alembic, $15 \mu \mathrm{g}$ ), streptomycin (Synbiotics, $10 \mu \mathrm{g}$ ), trimethoprim-sulfamethoxazole $(1: 5)$ (Piramal Health Care, $5 \mu \mathrm{g}$ ) and vancomycin (Lilly Pharma and Himedia, $30 \mu \mathrm{g}$ ). S. aureus ATCC 25923, an all-sensitive reference strain, was used as a quality control strain for the DAD test.

Determination of MIC. The MIC of vancomycin was determined by a broth microdilution method using Mueller-Hinton broth (MHB; dehydrated, Himedia), as recommended by the National Committee for Clinical Laboratory Standards (NCCLS) (NCCLS, 2000).

Isolation of plasmid DNAs. For molecular studies, plasmid DNAs from the clinical isolate S. aureus STM2 and the reference strain E. coli V517, which contains six plasmids of molecular weights 53.4, 5.5, 5.1, 3, 2.7 and $2.1 \mathrm{~kb}$ (Macrina et al., 1978), were isolated using the QIAGEN Midi plasmid purification kit, following the manufacturer's instruction of prewarming the elution buffer (Buffer EB) to $50{ }^{\circ} \mathrm{C}$ for elution of large plasmids.

Preparation of genomic DNA. The crude lysates of clinical isolates of S. aureus STM2 (VRSA), MC48 (vancomycin-sensitive S. aureus; VSSA) and T48 (transconjugant) were prepared by sucrose-mediated detergent lysis (Saha et al., 1989). Cell lysates were treated with proteinase $\mathrm{K}\left(10 \mu \mathrm{g} \mathrm{ml}{ }^{-1}\right.$, preactivated at $37^{\circ} \mathrm{C}$ for $\left.30 \mathrm{~min}\right)$ at room temperature for $30 \mathrm{~min}$. $\mathrm{NaCl}(1.44 \mathrm{ml}, 5 \mathrm{M})$ was added to this mixture and incubated at $65{ }^{\circ} \mathrm{C}$ for $20 \mathrm{~min}$. An equal volume of chloroform : isoamyl alcohol $(24: 1, \mathrm{v} / \mathrm{v})$ mixture was added, and the aqueous layer was extracted with an equal volume of phenol: chloroform : isoamyl alcohol $(25: 24: 1, \mathrm{v} / \mathrm{v})$. The aqueous phase was again extracted twice with chloroform: isoamyl alcohol $(24: 1, \mathrm{v} / \mathrm{v})$, and DNA was precipitated by the addition of chilled ethanol. The DNA pellet was washed with cold $70 \%$ ethanol and reconstituted in Tris/ EDTA buffer. The genomic DNA was treated with RNase and stored at $-20{ }^{\circ} \mathrm{C}$.

PCR. PCR amplification was performed with an ABI 9700 thermal cycler in a volume of $50 \mu \mathrm{l}$. For amplification of the $n u c$ gene and $m e c A$, the following components were used: $1.5 \mathrm{mM} \mathrm{MgCl}_{2}, 200 \mu \mathrm{M}$ each of dATP, dTTP, dGTP and dCTP, $2 \mu \mathrm{M}$ of each primer, $0.1 \mu \mathrm{g}$ template DNA, and 1.25 U Taq polymerase (Invitrogen).

(i) PCR amplification of the nuc gene. A partial $n u c$ gene was amplified using nuc gene primers (Table 1), which were selected on the basis of the published nucleotide sequence of the 966 bp nuc gene derived from the S. aureus Foggi strain (Brakstad et al., 1992). The cycling parameters consisted of 30 cycles of denaturation at $94{ }^{\circ} \mathrm{C}$ for $30 \mathrm{~s}$, primer annealing at $50{ }^{\circ} \mathrm{C}$ for $1 \mathrm{~min}$, and extension at $72{ }^{\circ} \mathrm{C}$ for $1 \mathrm{~min} 30 \mathrm{~s}$.

(ii) PCR amplification of mecA. For amplification of mecA, oligonucleotide primers (Table 1) were used (Dias et al., 2004). The reaction conditions were 30 cycles of denaturation at $94{ }^{\circ} \mathrm{C}$ for $40 \mathrm{~s}$, primer annealing at $52{ }^{\circ} \mathrm{C}$ for $45 \mathrm{~s}$, and extension at $72{ }^{\circ} \mathrm{C}$ for $30 \mathrm{~s}$.

(iii) PCR amplification of vanHAX, vanH, vanA and vanX. The PCR amplification mixture contained the following components: $1 \times$ Phusion GC buffer containing $1.5 \mathrm{mM} \mathrm{MgCl}_{2}, 200 \mu \mathrm{m}$ each dNTP, $2 \mu \mathrm{m}$ each primer, $0.1 \mu \mathrm{g}$ template DNA, $3 \%(\mathrm{v} / \mathrm{v}) \mathrm{DMSO}$ and $1 \mathrm{U}$ Phusion DNA polymerase (Finnzymes). The amplification conditions were initial denaturation at $98{ }^{\circ} \mathrm{C}$ for $2 \mathrm{~min}$, followed by 35 cycles of denaturation at $98{ }^{\circ} \mathrm{C}$ for $10 \mathrm{~s}$; annealing at $50{ }^{\circ} \mathrm{C}$ for $1 \mathrm{~min}$; polymerization at $72{ }^{\circ} \mathrm{C}$ for $1 \mathrm{~min} 30 \mathrm{~s}$ for van $H A X, 60 \mathrm{~s}$ for both vanH and vanA, and $30 \mathrm{~s}$ for vanX; and final extension at $72{ }^{\circ} \mathrm{C}$ for $5 \mathrm{~min}$ for all. The primer sequences specific for vanHAX, vanH, vanA and $\operatorname{vanX}$ (Donabedian et al., 2000) are given in Table 1.

Transfer of vancomycin resistance by mating procedure. Broth mating (Clewell et al., 1985; Philippon et al., 1983) was performed as 
Table 1. Sequences of primers and sizes of PCR-amplified products of different genes of S. aureus

All primers were obtained from Clonitec. The references of the primers are as follows: nuc (Brakstad et al., 1992); 16S rRNA of S. aureus (Woo et al., 2003); mecA (Dias et al., 2004); vanHAX (Donabedian et al., 2000); vanH, vanA and vanX (this study).

\begin{tabular}{|c|c|c|c|c|c|}
\hline $\begin{array}{l}\text { Specific gene for } \\
\text { amplification }\end{array}$ & Primer & Primer sequence $\left(5^{\prime}-3^{\prime}\right)$ & Strain no. & $\begin{array}{c}\text { Expected size of } \\
\text { amplicon }\end{array}$ & $\begin{array}{c}\text { Product (amplicon) } \\
\text { obtained }\end{array}$ \\
\hline \multirow[t]{2}{*}{ nuc } & Forward & GCGATTGATGGTGATACGGTT & VRSASTM2 & $270 \mathrm{bp}$ & $270 \mathrm{bp}$ \\
\hline & Reverse & AGCCAAGCCTTGACGAACTAAAGC & & & \\
\hline \multirow[t]{4}{*}{$16 \mathrm{~S}$ rRNA of $S$. aureus } & Forward & AGTTTGATCCTGGCTCAG & VRSASTM2 & $1.5 \mathrm{~kb}$ & $1.5 \mathrm{~kb}$ \\
\hline & & & MC48 & $1.5 \mathrm{~kb}$ & $1.5 \mathrm{~kb}$ \\
\hline & Reverse & AGGCCCGGGAACGTATTCAC & STM2-I & $1.5 \mathrm{~kb}$ & $1.5 \mathrm{~kb}$ \\
\hline & & & $\mathrm{T} 48$ & $1.5 \mathrm{~kb}$ & $1.5 \mathrm{~kb}$ \\
\hline \multirow[t]{2}{*}{$m e c A$} & Forward & TGGCTATCGTGTCACAATCG & VRSASTM2 & $310 \mathrm{bp}$ & $350 \mathrm{bp}$ \\
\hline & Reverse & CTGGAACTTGTTGAGCAGAG & & & \\
\hline \multirow[t]{4}{*}{ vanHAX } & Forward & ATGAATAACATCGGCATTAC & VRSASTM2 & $2.6 \mathrm{~kb}$ & $2.6 \mathrm{~kb}$ \\
\hline & & & & & $2.3 \mathrm{~kb}$ \\
\hline & Reverse & TTATTTAACGGGGAAATC & STM2-I & & $2.3 \mathrm{~kb}$ \\
\hline & & & $\mathrm{T} 48$ & & $2.3 \mathrm{~kb}$ \\
\hline \multirow[t]{3}{*}{$\operatorname{van} H$} & Forward & ATGAATAACATCGGCATTAC & VRSASTM2 & $969 \mathrm{bp}$ & $1 \mathrm{~kb}$ \\
\hline & & & STM2-I & & $1 \mathrm{~kb}$ \\
\hline & Reverse & CTATTCATGCTCCTGTCTCC & $\mathrm{T} 48$ & & $1 \mathrm{~kb}$ \\
\hline \multirow[t]{2}{*}{ vanA } & Forward & ATGAATAGAATAAAAGTTGC' & VRSASTM2 & $1032 \mathrm{bp}$ & $1.1 \mathrm{~kb}$ \\
\hline & Reverse & TCACСССТTTAACGCTAATA & & & \\
\hline \multirow[t]{3}{*}{$\operatorname{van} X$} & Forward & ATGGAAATAGGATTTACTTT & VRSASTM2 & $609 \mathrm{bp}$ & $600 \mathrm{bp}$ \\
\hline & & & STM2-I & & $600 \mathrm{bp}$ \\
\hline & Reverse & TTATTTAACGGGGAAATC- & $\mathrm{T} 48$ & & $600 \mathrm{bp}$ \\
\hline
\end{tabular}

follows. Single colonies of donor and recipient cells were inoculated separately in Luria-Bertani (LB) broth and grown overnight at $37{ }^{\circ} \mathrm{C}$ with shaking. These overnight cultures were diluted $1: 100$ in fresh medium, and each was grown to early exponential phase $\left(\mathrm{OD}_{600}\right.$ 0.6). Mating mixture was prepared by adding $0.1 \mathrm{ml}$ of donor cells to $0.9 \mathrm{ml}$ of recipient cells, and was swirled gently for a few minutes and then incubated at $37^{\circ} \mathrm{C}$ for $6 \mathrm{~h}$ (without shaking), followed by plating $(0.2 \mathrm{ml}$ per plate) on Luria agar (LA) medium containing $16 \mu \mathrm{g}$ vancomycin $\mathrm{ml}^{-1}$ and $2.5 \mu \mathrm{g}$ ciprofloxacin $\mathrm{ml}^{-1}$. Colonies were counted after 48 and $72 \mathrm{~h}$ of incubation. Donor and recipient cells were also plated separately to check their disability to grow on the vancomycin plus ciprofloxacin plate, because the donor was ciprofloxacin-sensitive and the recipient was susceptible to vancomycin.

Nucleotide sequencing. Amplified PCR products (vanHAX and vanH) were purified with the Wizard SV Gel and PCR Clean Up System (Promega). The gel-eluted PCR products were sequenced with an ABI Prism automated DNA sequencer (Applied Biosystems) with the single primer (forward primer for $v a n H$, reverse primer for vanHAX). The sequencing reaction was carried out using 5 pmol primer and the BigDye Terminator v3.1 Cycle Sequencing kit (Applied Biosystems), following the instructions of the manufacturer. The sequencing amplification conditions were as follows: $96{ }^{\circ} \mathrm{C}$ for $10 \mathrm{~s}, 50{ }^{\circ} \mathrm{C}$ for $10 \mathrm{~s}$ and $60{ }^{\circ} \mathrm{C}$ for $4 \mathrm{~min}$ for 25 cycles. After the sequencing PCR, the products $(10 \mu \mathrm{l}$ reaction volume $)$ were treated with $2 \mu \mathrm{l} 125 \mathrm{mM}$ EDTA ( $\mathrm{pH} 8.0$ ), and then precipitated using $2 \mu \mathrm{l}$ $3 \mathrm{M}$ sodium acetate ( $\mathrm{pH} 4.6)$ and $50 \mu \mathrm{l}$ absolute ethanol for $20 \mathrm{~min}$ at room temperature (in the dark). The DNA was recovered by centrifugation, washed with $70 \%$ alcohol, dried and resuspended in $15 \mu \mathrm{l} \mathrm{Hi-Di}$ formamide (Applied Biosystems). Sequencing was performed in an ABI PRISM 3130 Genetic Analyzer. Raw sequences were edited and assembled using the Auto Assembler program. The resulting sequences were used for identification with the help of the NCBI BLASTN program.

\section{RESULTS AND DISCUSSION}

\section{Source and identification of strain}

The clinical isolate S. aureus STM2, which was found to be VRSA, was obtained from the School of Tropical Medicine (STM), Kolkata. The strain was isolated from the pus of an outpatient. No other case history could be found. Isolates MC48 and MC50 were obtained from pus samples from separate patients at the Calcutta Medical College and Hospitals.

The clinical isolates were identified using standard biochemical tests. All were catalase- and coagulase-positive. The isolates took $72 \mathrm{~h}$ to grow in mannitol-salt $(10 \%$ $\mathrm{NaCl}$ ) agar medium.

The thermostable nuclease-encoding nuc gene is highly specific for S. aureus. PCR amplification of the nuc gene of VRSA STM2 using the gene-specific primers (Table 1) and the chromosomal DNA preparation yielded a $270 \mathrm{bp}$ amplicon, as expected (data not shown). This result confirmed VRSA STM2 as an S. aureus strain.

PCR amplification of 16S rDNA of the clinical isolates VRSA STM2 and S. aureus MC48 using primers specific for staphylococcal $16 \mathrm{~S}$ rRNA (Table 1) produced an identical 
$1.5 \mathrm{~kb}$ amplicon of $16 \mathrm{~S} \mathrm{rDNA}$ in both the strains (Woo et al., 2003). The VRSA STM2 with a vancomycin MIC of $1024 \mu \mathrm{g} \mathrm{ml}^{-1}$ was named STM2-I (induced STM2). An identical $1.5 \mathrm{~kb}$ amplicon was also obtained from STM2-I and the transconjugant T48. These PCR results again confirmed the identity of MC48, STM2, STM2-I and T48 as $S$. aureus.

\section{Antimicrobial susceptibility tests}

On initial testing, the growth of VRSA STM2 on the NA screen plate containing $32 \mu \mathrm{g}$ vancomycin $\mathrm{ml}^{-1}$ suggested possible vancomycin resistance. Further confirmation of vancomycin resistance was obtained from the DAD test, since no zone of inhibition surrounding the vancomycin disc was noted.

The VRSA STM2 isolate was resistant to many antibiotics, i.e. amoxicillin, ampicillin, cefepime, cefotaxime, cefuroxime, cephalexin, chloramphenicol, clindamycin, erythromycin, meticillin, rifampicin, roxithromycin, streptomycin, trimethoprim-sulfamethoxazole and vancomycin. However, it was susceptible to gentamicin and ciprofloxacin, as determined by the DAD test (Table 2).

The MIC of vancomycin for the VRSA STM2 isolate was found to be $64 \mu \mathrm{g} \mathrm{ml}^{-1}$, which confirmed it as VRSA by NCCLS criteria. However, the MIC value increased to $1024 \mu \mathrm{g} \mathrm{ml}{ }^{-1}$ after subculturing of this strain in the presence of vancomycin. This observation indicates the inducible nature of the vancomycin resistance of VRSA STM2. It has been suggested by Arthur and co-workers that the vanA gene cluster (vanR, vanS, vanH, vanA and vanX) carried by $\operatorname{Tn} 1546$ is responsible for inducible resistance to high levels of glycopeptides in Ent. faecium BM4147 and Ent. faecalis (Arthur et al., 1993; Reynolds et al., 1994). This suggestion validates our observation of an increasing MIC value for vancomycin (64 to $1024 \mu \mathrm{g} \mathrm{ml}^{-1}$ ), and the inducible nature of resistance to high levels of vancomycin in VRSA STM2 might be due to the presence of the vanA gene cluster. The PCR and sequencing experiments further confirmed the presence of the vanA gene cluster (discussed below). Glycopeptide antibiotics, vancomycin and teicoplanin, are used to treat severe infections due to

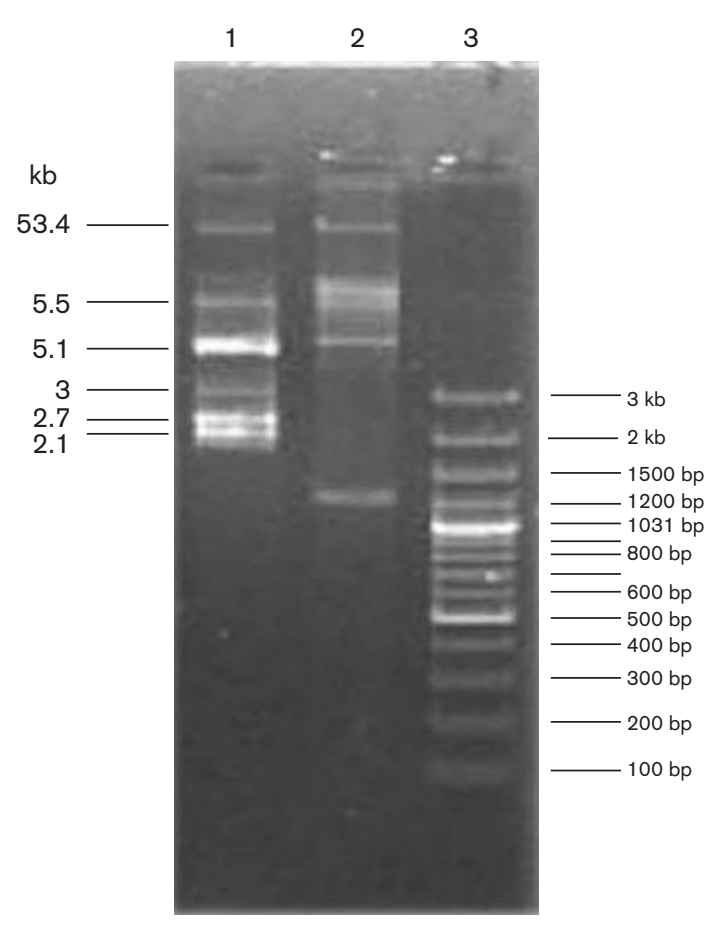

Fig. 1. Agarose gel electrophoresis of plasmid DNAs isolated from VRSA STM2 and E. coli V517. Lanes: 1, plasmid DNAs of $E$. coli V517 as molecular size marker; 2, plasmid DNAs of VRSA STM2; 3, 100 bp DNA ladder.

multidrug-resistant Gram-positive bacteria (including MRSA). However, treatment with vancomycin to alleviate this type of bacterial infection that has inducible resistance to high levels of the antibiotic itself would be a therapeutic failure, and might even be fatal for the patient.

\section{Plasmid analysis}

The plasmid profile of VRSA STM2 revealed five plasmids: one large plasmid of $\sim 53.4 \mathrm{~kb}$, and four small plasmids of $\sim 6, \sim 5.5, \sim 5.1$ and $\sim 1.5 \mathrm{~kb}$, when compared with the molecular size of plasmid markers of the reference strain $E$. coli V517 (Fig. 1).

Table 2. Antibiogram of clinical isolates of $S$. aureus

Results of DAD test of clinical isolates of S. aureus. Abbreviations: AMP, ampicillin; AMX, amoxicillin; CHL, chloramphenicol; CIP, ciprofloxacin; CLI, clindamycin; CTX, cefotaxime; CXM, cefuroxime; ERY, erythromycin; FEP, cefepime; GEN, gentamicin; LEX, cephalexin; MET, meticillin; RIF, rifampicin; ROX, roxithromycin; STR, streptomycin; SXT, trimethoprim-sulfamethoxazole; VAN, vancomycin; R, resistant; S, sensitive.

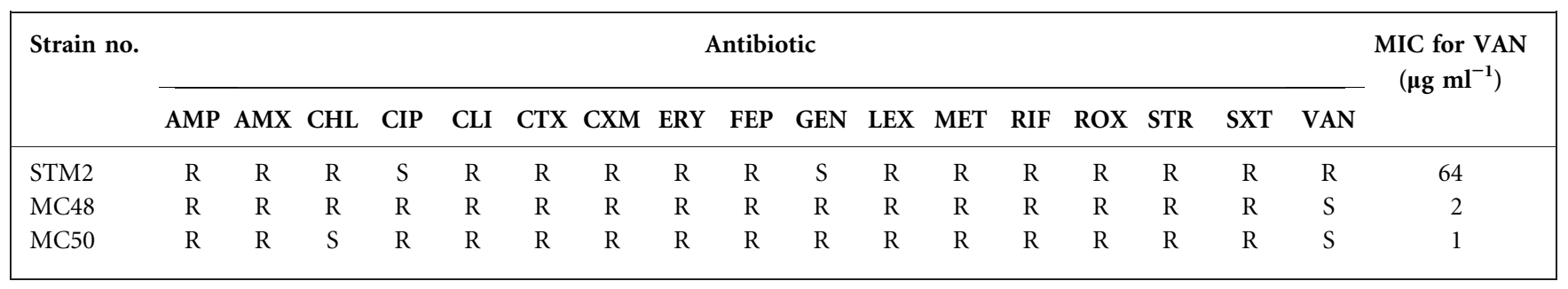




\section{Transfer of vancomycin resistance by transconjugation}

Twenty-one transconjugant colonies were found on LA plates containing appropriate selective antibiotics $(16 \mu \mathrm{g}$ vancomycin $\mathrm{ml}^{-1}$ and $2.5 \mu \mathrm{g}$ ciprofloxacin $\mathrm{ml}^{-1}$ ) taking VRSA STM2 (ciprofloxacin-sensitive) as a donor, and vancomycin-sensitive ciprofloxacin-resistant $S$. aureus MC48 as a recipient (Table 2). However, no transconjugant colony was found on the above LA medium with VRSA STM2 as the donor and vancomycin-sensitive ciprofloxacin-resistant S. aureus MC50 (Table 2) as the recipient. No growth of recipient $S$. aureus strains MC48 and MC50, and the donor strain VRSA STM2, was observed on the above LA medium when inoculated separately. A selected transconjugant (named S. aureus T48) was observed to grow even after three successive overnight passages on NA plates containing $32 \mu \mathrm{g}$ vancomycin $\mathrm{ml}^{-1}$. This indicated successful and stable transfer of vancomycin resistance from the clinical isolate VRSA STM2 donor to another clinical isolate $S$. aureus MC48 as recipient. While the MIC of vancomycin for the transconjugant T48 was $32 \mu \mathrm{g} \mathrm{ml}^{-1}$, that of the recipient $S$. aureus MC48 strain was $2 \mu \mathrm{g} \mathrm{ml}^{-1}$.

\section{PCR-based detection of vancomycin-resistance genes (vanHAX, vanH, vanA and van $X$ ) and mecA in VRSA STM2}

Initially, genomic DNA was used as template for PCR amplification of vanHAX, vanH and $\operatorname{vanX}$, using primers specific for vanHAX (2.6 kb), vanH (969 bp) and vanX (609 bp) (Donabedian et al., 2000), as shown in Table 1. PCR products of $2.6 \mathrm{~kb}$ for vanHAX, $1 \mathrm{~kb}$ for $v a n H$ and $600 \mathrm{bp}$ for vanX were obtained, which suggests the presence of the vanHAX gene cassette in VRSA STM2.

Later, the plasmid preparation obtained using the QIAGEN kit was used as template for PCR amplification of vanHAX (2.61 kb), vanH (969 bp), vanA (1032 bp) and vanX (609 bp) with the appropriate primers. Amplicons of $2.6 \mathrm{~kb}$ for vanHAX, 1 kb for vanH, $\sim 1.1 \mathrm{~kb}$ for vanA and $\sim 500$ bp for $\operatorname{vanX}$ were obtained (Fig. 2). The results confirmed the possession of van genes by the plasmid(s) of VRSA STM2. Most probably, the genomic DNA preparation had plasmid DNA contamination, and that was the reason for obtaining PCR products of vanHAX using genomic DNA as template.

Finally, the specific plasmid(s) that harboured the van genes was identified. Each plasmid was eluted from the gel, purified by using the gel-extraction kit (Promega), and used as template for PCR amplification of vanHAX, vanH, vanA and $\operatorname{van} X$ separately using the specific primers for those genes (Table 1). Only in the case of the $53.4 \mathrm{~kb}$ plasmid were the same amplicons obtained as by PCR using the whole plasmid preparation (containing all the plasmids of different sizes) as template (Fig. 2). This result clearly established that the $53.4 \mathrm{~kb}$ plasmid harbours the vancomycin-resistance gene cluster vanHAX in VRSA STM2.

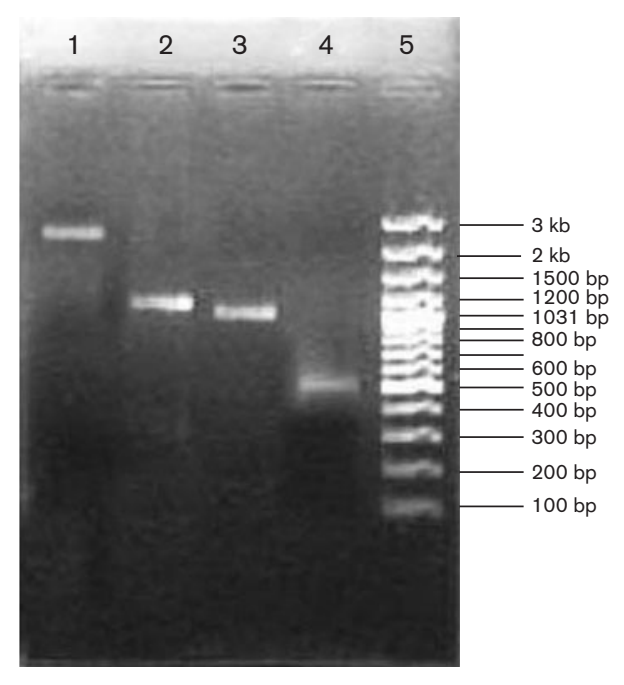

Fig. 2. Agarose gel electrophoresis of $P C R$-amplified vancomycin-resistance genes of VRSA STM2 using plasmid DNA as template. Lanes: 1, PCR-amplified product of vanHAX; 2, PCRamplified product of vanA; 3, PCR-amplified product of vanH; 4, PCR-amplified product of vanX; 5, 100 bp DNA ladder as molecular size marker.

A $2.3 \mathrm{~kb}$ amplicon was also obtained from STM2-I and transconjugant T48 using primers specific for the vanHAX gene cassette. A $1 \mathrm{~kb}$ amplicon was obtained from VRSA STM2, STM2-I and transconjugant T48 using primers specific for the vanH gene (969 bp) (Fig. 3, Table 1). However, no 2.3 or $1 \mathrm{~kb}$ amplicon was observed in the case of VSSA MC48 (Fig. 3). A $600 \mathrm{bp}$ amplicon was also obtained from VRSA STM2, STM2-I and transconjugant T48 using primers specific for the $\operatorname{vanX}$ gene $(609 \mathrm{bp})$ (data not shown). However, no such amplicon was observed in the case of VSSA MC48 using these primers. These results suggested the presence of a vanA gene cassette in VRSA STM2 and STM2-I that mediates high-level vancomycin resistance through alterations of the PG layer of the cell wall and cell-wall metabolism.

PCR amplification of vanHAX, vanH and vanX of transconjugant T48 (Fig. 3) clearly indicated the transfer of the same vancomycin-resistance genes vanHAX from the donor VRSA STM2 to the recipient VSSA MC48.

The meticillin resistance of VRSA STM2 was verified by PCR amplification of the mecA gene; an amplicon of $0.3 \mathrm{~kb}$ was obtained (data not shown).

\section{Nucleotide sequencing}

Nucleotide sequencing of 652 bases (GenBank accession no. EU019995) with the forward primer of the $1 \mathrm{~kb}$ PCR product of $v a n H$ showed $47 \%$ homology with the nucleotide sequence of the $\mathrm{VanH}$ dehydrogenase of the Tn1546-like element, and $44 \%$ homology with Tn1549 (Garnier et al., 2000). VanH dehydrogenase reduces 


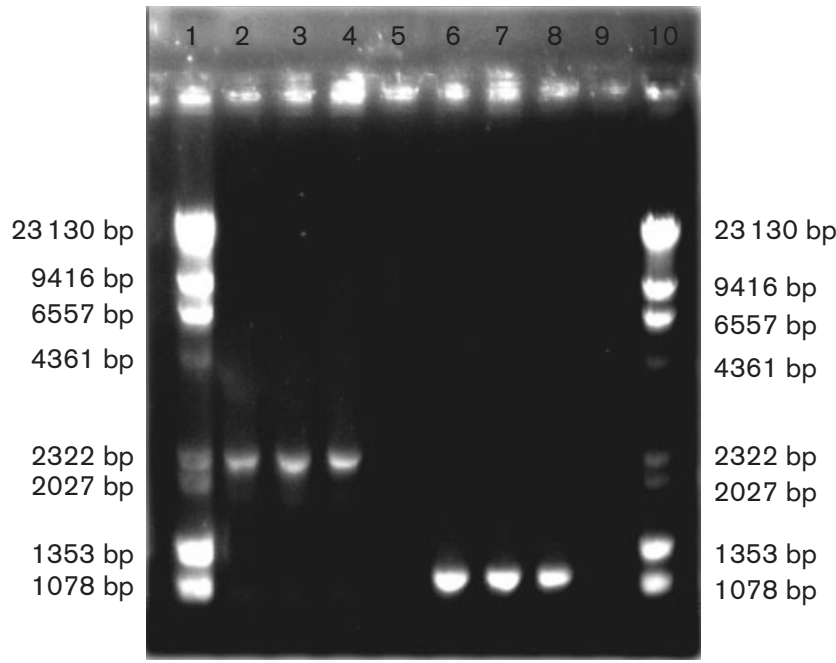

Fig. 3. Agarose gel electrophoresis of PCR-amplified genes of VRSA STM2, induced VRSA STM2 (STM2-I), transconjugant (T48) and VSSA MC48. Lanes: 1 and 10, mix of lambda DNA Hindlll digest and bacteriophage $\Phi$ X174 DNA Haell digest as size and mass standard; 2, 3 and 4, amplicons of vanHAX of STM2, STM2-I and T48, respectively; 5 and 9, MC48; 6, 7 and 8, amplicons of vanH of STM2, STM2-I and T48, respectively.

pyruvate to lactate, one of the building blocks of the PG layer of the cell wall of $S$. aureus. VanH dehydrogenase, which is functionally like lactate dehydrogenase, is a common metabolic enzyme required for glycolysis and the tricarboxylic acid (TCA) cycle (carbohydrate metabolism), and is ubiquitous in nature. Accordingly, in the VRSA STM2 strain, a mechanism exists that facilitates the expression of VanH dehydrogenase and VanA ligase to form D-Ala-D-lactate. Nucleotide sequencing of 272 bases with the reverse primer of the $2.3 \mathrm{~kb}$ PCR product of vanHAX produced a sequence (GenBank accession no. EU016096) that had $45 \%$ homology with, and a region of 21 bases identical to, the Tn1546-like element that contains the vanHAX gene cluster. This sequence also showed $56 \%$ homology with $\operatorname{Tn} 1549$, which is responsible for vanB-type vancomycin resistance in Ent. faecalis (Garnier et al., 2000). However, the PCR product vanA (Fig. 2) was obtained using the $53.4 \mathrm{~kb}$ plasmid of VRSA STM2 as template and the primers specific for vanA of the Tn1546-like element. The vanA gene is absent in the $v a n B$ operon of $\operatorname{Tn} 1549$, which has vanR, $-S,-H,-B$ and $-X$. Accordingly, we may conclude that the vancomycin resistance exhibited by VRSA STM2 is of the vanA type due to the presence of vanHAX analogous to that of the Tn1546-like element. These facts suggest that the VRSA isolate STM2 could have a modified van gene cassette that confers vancomycin resistance. The occurrence of partial sequence similarity might be due to multiple mutations that occurred during multiple replication (many thousand times) of bacterial genes having species specificity and species diversity, or during inter-species mobilization of resistance genes or gene acquisition. Modification of the van gene complex in the Pennsylvania VRSA isolate (the second documented clinical VRSA isolate) has been reported by Clark et al. (2005); it has a deletion of $3098 \mathrm{bp}$, and two insertions of 809 and 1499 bp. Modification of the van gene complex in the New York VRSA isolate (the third documented clinical VRSA isolate) has also been reported by Weigel et al. (2007).

Intergeneric transfer of high-level vancomycin resistance from Ent. faecalis to $S$. aureus has been demonstrated by Noble et al. (1992). Intrageneric transfer of such high-level vancomycin and other antibiotic resistance from $S$. aureus to S. aureus has also been reported (Severin et al., 2004; Pawa et al., 2000). However, in this study, we have demonstrated intrageneric transfer of vancomycin resistance from a clinical strain of $S$. aureus to another clinical isolate of $S$. aureus, which has alarming implications for the global dissemination of such high-level glycopeptide resistance in clinical settings with no known effective antibiotic therapy for some Gram-positive bacterial infections.

In summary, the major new findings of the present study are:

(1) This is believed to be the first report of VRSA containing mecA and the vanA gene complex from Kolkata, India, as well as South Asia.

(2) The vancomycin resistance of the clinical isolate VRSA STM2 is inducible in vitro.

(3) PCR amplification and nucleotide sequencing experiments suggest the presence of a vanHAX-type gene cluster, analogous to that of the Tn1546-like element, in VRSA STM2 and transconjugant T48.

(4) The vancomycin resistance obtained in VRSA STM2 is plasmid-mediated and transferable to a sensitive clinical isolate (as found for VSSA MC48).

The emergence of inducible VRSA in Kolkata, India (as well as in South Asia), and its intrageneric transfer is alarming. This may soon become a global problem, unless antimicrobial agents are used more prudently. Scientists, clinicians and other healthcare professionals should identify and report VRSA promptly for appropriate care and treatment of patients, and start to implement infection-control precautions to prevent the spread of VRSA.

\section{ACKNOWLEDGEMENTS}

We gratefully acknowledge financial help from the Department of Science and Technology, Kolkata, Government of West Bengal, for this work. We express our sincere thanks to Professor N. K. Pal, Head, Department of Bacteriology, School of Tropical Medicine, Kolkata, and Professor Aparna Lahiri, Head, Department of Microbiology, Calcutta Medical College and Hospital, Kolkata, for providing us with clinical strains of $S$. aureus. We have no words to express our deep gratitude to Dr Manikuntala Kundu and Dr Joyoti Basu, Department of Chemistry, Bose Research Institute, Kolkata, for helping us in 
performing PCR experiments. We are grateful to Professor Uma Dasgupta of the Department of Biophysics, Molecular Biology and Genetics, Calcutta University, for providing us with the UV/visible Gel Documentation System (Bio-Rad). We are very much obliged to Dr P. C. Banerjee, Emeritus Scientist, Indian Institute of Chemical Biology, Jadavpur, Kolkata, for helping us with valuable guidance and suggestions during the progress of this work. Finally, we are thankful to Professor D. J. Chattopadhaya, Head, Dr B. C. Guha Centre for Genetic Engineering and Biotechnology, University of Calcutta, for helping us in performing nucleotide sequencing and in preparing this manuscript. In this study, the DNA sequencing facility of the Dr B. C. Guha Centre for Genetic Engineering and Biotechnology, developed with a National Common Minimum Programme (NCMP) grant from Calcutta University, was utilized.

\section{REFERENCES}

Acar, J. F. (1980). The disc susceptibility test. In Antibiotics in Laboratory Medicine, pp. 24-25. Edited by V. Lorian. Baltimore: Williams \& Wilkins.

Arthur, M., Molinas, C., Depardieu, F. \& Courvalin, P. (1993). Characterization of Tn1546, a Tn3-related transposon conferring glycopeptide resistance by synthesis of depsipeptide peptidoglycan precursors in Enterococcus faecium BM4147. J Bacteriol 175, 117-127.

Bannerman, T. L. (2003). Staphylococcus, Micrococcus, other catalasepositive cocci that grow aerobically. In Manual of Clinical Microbiology, pp. 384-404. Edited by P. R. Murray, E. J. Baron, J. H. Jorgensen, M. A. Pfaller \& R. H. Yolken. Washington, DC: ASM Press.

Bauer, A. W., Kirby, W. M., Sherris, J. C. \& Turck, M. (1966). Antibiotic susceptibility testing by a standardized single disk method. Am J Clin Pathol 45, 493-496.

Brakstad, O. G., Aasbakk, K. \& Maeland, J. A. (1992). Detection of Staphylococcus aureus by polymerase chain reaction amplification of the nuc gene. J Clin Microbiol 30, 1654-1660.

Bugg, T. D. H., Wright, G. D., Dutka-Malen, S., Arthur, M., Courvalin, P. \& Walsh, C. T. (1991a). Molecular basis for vancomycin resistance in Enterococcus faecium BM4147: biosynthesis of a depsipeptide peptidoglycan precursor by vancomycin resistance proteins VanH and VanA. Biochemistry 30, 10408-10415.

Bugg, T. D. H., Dutka-Malen, S., Arthur, M., Courvalin, P. \& Walsh, C. T. (1991b). Identification of vancomycin resistance protein VanA as a D-alanine:D-alanine ligase of altered substrate specificity. Biochemistry 30, 2017-2021.

CDC (1997). Reduced susceptibility of Staphylococcus aureus to vancomycin - Japan, 1996. MMWR Morb Mortal Wkly Rep 46, 624-626.

CDC (2004). Brief report: vancomycin-resistant Staphylococcus aureus - New York, 2004. MMWR Morb Mortal Wkly Rep 53, 322-323.

Chambers, H. F. (2001). The changing epidemiology of Staphylococcus aureus? Emerg Infect Dis 7, 178-182.

Chang, S., Sievert, D. M., Hageman, J. C., Boulton, M. L., Tenover, F. C., Downes, F. P., Shah, S., Rudrik, J. T., Pupp, G. R. \& other authors (2003). Infection with vancomycin-resistant Staphylococcus aureus containing the vanA resistance gene. $N$ Engl J Med 348, 1342-1347.

Clark, N. C., Weigel, L. M., Patel, J. B. \& Tenover, F. C. (2005). Comparison of Tn1546-like elements in vancomycin-resistant Staphylococcus aureus isolates from Michigan and Pennsylvania. Antimicrob Agents Chemother 49, 470-472.

Clewell, D. B., An, F. Y., White, B. A. \& Gawron-Burke, C. (1985). Streptococcus faecalis sex pheromone (cAM373) also produced by
Staphylococcus aureus and identification of a conjugative transposon (Tn918). J Bacteriol 162, 1212-1220.

Dias, C. G., Rosa Ropke, V. R., Superti, S., Berquo, L. \& Azevedo, P. (2004). Use of a novel selective medium to detect methicillin-resistant Staphylococcus aureus in colonized patients of an intensive care unit. Infect Contro Hosp Epidemic 25, 130-132.

Dickgiesser, N. \& Kreiswirth, B. N. (1986). Determination of aminoglycoside resistance in Staphylococcus aureus by DNA hybridization. Antimicrob Agents Chemother 29, 930-932.

Donabedian, S., Hershberger, E., Thal, L. A., Chow, J. W., Clewell, D. B., Dunn, B. R. \& Zervos, M. J. (2000). PCR fragment length polymorphism analysis of vancomycin-resistant Enterococcus faecium. J Clin Microbiol 38, 2885-2888.

Garnier, F., Taourit, S., Glaser, P., Courvalin, P. \& Galimand, M. (2000). Characterization of transposon Tn1549, conferring VanB-type resistance in Enterococcus spp. Microbiology 146, 1481-1489.

Kim, M. N., Pai, C. H., Woo, J. H., Ryu, J. S. \& Hiramatsu, K. (2000). Vancomycin-intermediate Staphylococcus aureus in Korea. J Clin Microbiol 38, 3879-3881.

Levin, T. P., Suh, B., Axelrod, P., Truant, A. L. \& Fekete, T. (2005). Potential clindamycin resistance in clindamycin-susceptible, erythromycin-resistant Staphylococcus aureus: report of a clinical failure. Antimicrob Agents Chemother 49, 1222-1224.

Macrina, F. L., Kopecko, D. J., Jones, K. R., Ayers, D. J. \& Mc Cowen, S. M. (1978). A multiple plasmid-containing Escherichia coli strain: convenient source of size reference plasmid molecules. Plasmid 1, 417-420.

Młynarczyk, A., Młynarczyk, G. \& kuczak, M. (2002). Conjugative transfer of glycopeptide and macrolide resistant genes among enterococci and from Enterococcus faecalis to Staphylococcus aureus. Med Dosw Mikrobiol 54, 21-28 (in Polish).

Morse, S. I. (1980). Staphylococci. In Microbiology Including Immunology and Molecular Genetics, 3rd edn, pp. 623-633. Edited by B. D. Davis, R. Dulbecco, H. N. Eisen \& H. S. Ginsberg. Philadelphia, PA: Harper \& Row Publishers.

Munckhof, W. J., Harper, J., Schooneveldt, J. \& Nimmo, G. R. (2002). Recent appearance of clindamycin resistance in community-acquired methicillin-resistant Staphylococcus aureus (MRSA) in south-east Queensland. Med J Aust 176, 243-244.

NCCLS (2000). Methods for Dilution Antimicrobial Susceptibility Tests for Bacteria that Grow Aerobically, 5th edn, 17, no. 2. Approved standard M7-A5. Wayne, PA: NCCLS.

Noble, W. C., Virani, Z. \& Cree, R. G. (1992). Co-transfer of vancomycin and other resistance genes from Enterococcus faecalis NCTC 12201 to Staphylococcus aureus. FEMS Microbiol Lett 72, 195-198.

Pawa, A., Noble, W. C. \& Howell, S. A. (2000). Co-transfer of plasmids in association with conjugative transfer of mupirocin or mupirocin and penicillin resistance in methicillin-resistant Staphylococcus aureus. J Med Microbiol 49, 1103-1107.

Perichon, B. \& Courvalin, P. (2006). Synergism between beta-lactams and glycopeptides against vanA-type methicillin-resistant Staphylococcus aureus and heterologous expression of the vanA operon. Antimicrob Agents Chemother 50, 3622-3630.

Philippon, A. M., Paul, G. C. \& Jacoby, G. A. (1983). Properties of PSE2 beta-lactamase and genetic basis for its production in Pseudomonas aeroginosa. Antimicrob Agents Chemother 24, 362-369.

Reynolds, P. E., Depardieu, F., Dutka-Malen, S., Arthur, M. \& Courvalin, P. (1994). Glycopeptide resistance mediated by enterococcal transposon $\mathrm{Tn} 1546$ requires production of $\operatorname{vanX}$ for hydrolysis of D-alanyl-D-alanine. Mol Microbiol 13, 1065-1070. 
Saha, B., Saha, D., Niyogi, S. \& Bal, M. (1989). A new method of plasmid DNA preparation by sucrose-mediated detergent lysis from Escherichia coli (Gram-negative) and Staphylococcus aureus (Grampositive). Anal Biochem 176, 344-349.

Schmitz, F.-J., Sadurski, R., Kray, A., Boos, M., Geisel, R., Kohrer, K., Verhoef, J. \& Fluit, A. C. (2000). Prevalence of macrolide-resistance genes in Staphylococcus aureus and Enterococcus faecium isolates from 24 European university hospitals. J Antimicrob Chemother 45, 891-894.

Severin, A., Tabei, K., Tenover, F., Chung, M. \& Clarke, N. (2004). High level oxacillin and vancomycin resistance and altered cell wall composition in Staphylococcus aureus carrying the staphylococcal mecA and enterococcal vanA gene complex. J Biol Chem 279, 3398-3407.

Tenover, F. C., Weigel, L. M., Appelbaum, P. C., McDougal, L. K., Chaitram, J., McAllister, S., Clark, N., Killgore, G., O'Hara, C. M. \& other authors (2004). Vancomycin-resistant Staphylococcus aureus isolate from a patient in Pennsylvania. Antimicrob Agents Chemother 48, 275-280.
Tiwari, H. K. \& Sen, M. R. (2006). Emergence of vancomycin resistant Staphylococcus aureus (VRSA) from a tertiary care hospital from northern part of India. BMC Infect Dis 6, 156.

Turk, D. C. \& Porter, I. A. (1978). A Short Textbook of Medical Microbiology, 4th edn. London: Hodder and Stoughton.

Weigel, L. M., Donlan, R. M., Shin, D. H., Jensen, B., Clark, N. C., McDougal, L. K., Zhu, W., Musser, K. A., Thompson, J. \& other authors (2007). High-level vancomycin-resistant Staphylococcus aureus isolates associated with a polymicrobial biofilm. Antimicrob Agents Chemother 51, 231-238.

Woo, P. C. Y., Ng, K. H. L., Lau, S. K. P., Yip, K.-T., Fung, A. M. Y., Leung, K.-W., Tam, D. M. W., Que, T.-L. \& Yuen, K.-Y. (2003). Usefulness of the microSeq $50016 \mathrm{~S}$ ribosomal DNA-based bacterial identification system for identification of clinically significant bacterial isolates with ambiguous biochemical profiles. J Clin Microbiol 41, 1996-2001.

Wright, G. D., Holman, T. R. \& Walsh, C. T. (1993). Purification and characterization of VanR and the cytosolic domain of VanS: a twocomponent regulatory system required for vancomycin resistance in Enterococcus faecium BM4147. Biochemistry 32, 5057-5063. 